"Przegląd Prawa Konstytucyjnego" Nr $4(16) / 2013$

\title{
Sprawozdanie
}

\section{Konferencja naukowa Instytucjonalne gwarancje zasady pluralizmu politycznego $w$ Polsce na tle standardów europejskich, Nałęczów, 14-16 czerwca 2013 r.}

W dniach 14-16 czerwca 2013 r. w Nałęczowie odbyła się konferencja naukowa pod nazwą Instytucjonalne gwarancje zasady pluralizmu politycznego w Polsce na tle standardów europejskich, zorganizowana przez Zakład Prawa Konstytucyjnego Wydziału Administracji Wyższej Szkoły Ekonomii i Innowacji w Lublinie oraz Zakład Prawa Konstytucyjnego Porównawczego i Współczesnych Systemów Politycznych Wydziału Prawa i Administracji Uniwersytetu Kardynała Stefana Wyszyńskiego w Warszawie. Była to kolejna $\mathrm{z}$ cyklu konferencji poświęconych zagadnieniom prawa konstytucyjnego, organizowanych przez oba ośrodki naukowe. Zgromadziła około 50 uczestników z różnych ośrodków naukowych z całej Polski: z Warszawy, Łodzi, Krakowa, Wrocławia, Poznania, Katowic, Lublina, Rzeszowa i Olsztyna. Byli też obecni goście z ośrodków zagranicznych. Ilość referatów wygłaszanych na konferencji wynosiła tylko osiem, jednak, jak stwierdzili organizatorzy, wynika to ze specyfiki tych konferencji, nastawionych przede wszystkim na dyskusję i wymianę opinii odnośnie różnych kwestii związanych z prawem konstytucyjnym, co zadecydowało o takiej właśnie strukturze konferencyjnej.

Konferencję otworzyli główni jej organizatorzy: prof. dr hab. Bogumił Szmulik, kierownik Zakładu Prawa Konstytucyjnego Porównawczego i Współczesnych Systemów Politycznych w UKSW, oraz dr Mariusz Paździor, prodziekan Wydziału Administracji WSEI, którzy powitali gości i przedstawili ideę cyklu nałęczowskich konferencji. Następnie gości w imieniu dziekana Wydziału Prawa i Administracji UKSW powitał ks. prof. dr 
hab. Krzysztof Warchałowski, prodziekan wydziału, który podziękował organizatorom za wysiłek włożony w organizację konferencji oraz życzył owocnych obrad. Jako ostatni zabrał głos senator Piotr Zientarski reprezentujący Platformę Obywatelską, który podziękował za zaproszenie i zaprezentował swoją pracę w Senacie, polegającą na zajmowaniu się orzecznictwem Trybunału Konstytucyjnego oraz problematyką zmian w Konstytucji Rzeczypospolitej Polskiej.

Konferencja składała się z trzech paneli: dwóch sobotnich (15 czerwca) oraz jednego niedzielnego (16 czerwca). Pierwszemu panelowi sobotniemu przewodniczył prof. dr hab. Marek Chmaj z Uniwersytetu Warmińsko-Mazurskiego z Olsztyna. W tym panelu przeznaczono miejsce dla trzech referentów, z których każdy miał po pół godziny na zaprezentowanie swojego wystąpienia. Jako pierwszy zaprezentował swój referat prof. dr hab. Andrzej Szmyt z Uniwersytetu Łódzkiego pod tytułem Przeciwdziałanie opozycyjnej „obstrukcji poprawkowej” względem projektu ustawy budżetowej. Celem wystąpienia prof. Szmyta było ukazanie, w jaki sposób opozycja może w sposób legalny uniemożliwiać realizację procesu legislacyjnego i jak można temu zapobiec. Jako przykład prelegent podał działalność Sojuszu Lewicy Demokratycznej w 1999 r. oraz Ruchu Palikota w 2012 r., których przedstawiciele składali dużą ilość poprawek do ustaw budżetowych, chcąc uniemożliwić uchwalenie tej ustawy i skłonić prezydenta do skrócenia kadencji Sejmu. Prof. Szmyt przedstawił jednak instrumenty, dzięki którym strona rządząca może ograniczać taką działalność opozycji. Wśród nich wymienił między innymi ocenianie przez marszałka Sejmu, czy dana poprawka jest obstrukcyjna czy konstruktywna oraz wprowadzenie łączonego głosowania nad wszystkimi poprawkami.

Kolejną referentką była prof. dr hab. Anna Łabno z Uniwersytetu Śląskiego w Katowicach, która zaprezentowała wystąpienie pod tytułem Pluralizm a zasada solidaryzmu. Podjęła w nim rozważania na temat takich pojęć, jak „pluralizm” $i$ „solidaryzm” oraz kwestii, czy da się te dwa sprzeczne ze sobą zjawiska pogodzić. Z jednej strony bowiem pluralizm dla wielu oznacza wolność i indywidualizm, co stoi w sprzeczności z zasadą solidaryzmu, zakładającą istnienie więzi międzyludzkich i wzajemnych ograniczeń w stosunkach interpersonalnych. Prof. Łabno uznała, że najlepszym wyjściem byłoby znalezienie elementów lączących obie idee. Możliwe to będzie jednak tylko 
wtedy, kiedy z jednej strony uzna się, że pluralizm nie oznacza nieograniczonej wolności jednostek, $\mathrm{z}$ drugiej zaś strony solidaryzm, przy narzucaniu ludziom pewnych wspólnych i uniwersalnych zasad i ograniczeń, będzie szanował różnorodność osób i grup społecznych.

Ostatnim prelegentem w tej części konferencji był dr Bogusław Przywora z Uniwersytetu Jagiellońskiego w Krakowie. Jego wystąpienie nosiło tytuł Kontrola celów $i$ działalności partii politycznych w Polsce. Stan obecny i postulaty de lege ferrenda. W swoim referacie dr Przywora przedstawił prawne aspekty kontroli partii politycznych, zarówno przed ich rejestracją, jak i w trakcie działalności. Pierwsza z nich jest kontrolą prewencyjną i prowadzona jest przez Sąd Okręgowy w Warszawie, który ma za zadanie badać cele partii wyrażone w statucie i programach politycznych oraz decydować o jej rejestracji w rejestrze partii politycznych. Druga z nich to kontrola represyjna, realizowana przez Trybunał Konstytucyjny wobec partii zarejestrowanej, który bada, czy dana partia działa zgodnie z prawem i ma możliwość orzec o jej delegalizacji i wykreśleniu z rejestru partii politycznych. Po zakończeniu wystąpienia nastąpiła dyskusja, w której referenci odpowiadali na pytania, uwagi i refleksje uczestników konferencji.

Po obiedzie nastąpił drugi panel, któremu przewodniczył prof. dr hab. Sławomir Patyra z Uniwersytetu Marii Curie-Skłodowskiej w Lublinie. Tutaj również wyznaczono trzy półgodzinne wystąpienia. Jako pierwszy referent wystąpił prof. dr hab. Jan Filip z Uniwersytetu Tomasza Masaryka w Brnie (Republika Czeska). Zaprezentował on referat pod tytułem Zasada pluralizmu politycznego w praktyce oraz orzecznictwie Republiki Czeskiej. Główną ideą wystąpienia prof. Filipa było zaprezentowanie problemów, z jakimi borykają się konstytucjonaliści czescy, którzy próbują połączyć zasadę pluralizmu politycznego z wartościami demokratycznymi. Prelegent stwierdził, że w Czechach próbuje się od dawna określić granice wolnego dyskursu politycznego i pluralizmu, za którą już są nienaruszalne wartości i kwestie, których nie można poddać pod referendum. Jednakże ocenił, że jak na razie nie jest to możliwe, gdyż istnieją różne stanowiska w tej kwestii.

Kolejny referent, dr hab. Artur Ławniczak z Uniwersytetu Wrocławskiego, zaprezentował wystąpienie pod tytułem Pluralistyczne rozumienie pluralizmu (niekoniecznie $w$ duchu liberalizmu), w którym ukazał różne rozumienia słowa „pluralizm”. Jego zdaniem rozumienie znaczenia tego określenia 
zależy od różnych kontekstów, w jakich się pojawia, czyli od kultury, tradycji, systemu politycznego czy epoki historycznej danego państwa czy społeczeństwa. Stwierdził, że pluralizm można traktować między innymi w sensie politycznym, ale i filozoficznym, jako wielość instytucji władzy państwowej i podział kompetencji pomiędzy nimi, a także jako wielość cywilizacji, kultur, religii czy państw. Odnosząc się natomiast do polskiej sceny politycznej, dr hab. Ławniczak podkreślił, że po 1989 r. mieliśmy do czynienia z pluralizmem początkowego okresu, czyli mnogością partii politycznych, który stopniowo przekształcił się w pluralizm konstruktywny, oznaczający istnienie kilku dużych ugrupowań odpowiedzialnych za państwo.

Ostatnią prelegentką w tym panelu była dr Ksenia Kakareko z Uniwersytetu Warszawskiego, która przedstawiła referat pod tytułem Sytuacja prawna niekatolickich kościołów i związków wyznaniowych a konstytucyjne gwarancje równouprawnienia wspólnot religijnych. Celem przewodnim wystąpienia było ukazanie nierównoprawności różnych Kościołów i związków wyznaniowych w polskim prawie, z uprzywilejowaną pozycją Kościoła rzymskokatolickiego. Dr Kakareko stwierdziła, że religia, według przepisów Unii Europejskiej, jest kwestią prywatną obywateli i nie powinna być regulowana na poziomie centralnym, gdyż w ten sposób proces różnicowania różnych wyznań może się pogłębiać. Po tym wystąpieniu nastąpiła kolejna dyskusja nad problematyką poruszoną w referatach.

Niedzielny panel liczył dwóch prelegentów. Prowadził go prof. dr hab. Krzysztof Skotnicki z Uniwersytetu Łódzkiego. Jako pierwszy zabrał głos prof. dr hab. Jacek Sobczak z Uniwersytetu Adama Mickiewicza w Poznaniu w referacie pod tytułem Niezawisłość sędziowska i niezależność sądów i trybunatów a zasady tworzenia okręgów sądowych (między pluralizmem a partykularyzmem interesów sądowych). W swoim wystąpieniu prof. Sobczak zaprezentował trudną sytuację sądownictwa w chwili obecnej, które jest poddane coraz większej kontroli administracyjnej ze strony ministra sprawiedliwości. Wśród przykładów takiej ingerencji prelegent wymienił między innymi mianowanie przez ministra dyrektorów sądów, sprawujących nadzór nad pracownikami administracyjnymi wymiaru sprawiedliwości i często niezależnych w swoich działaniach od prezesów sądów, a także możliwość odwołania przez ministra prezesa i wiceprezesów sądów, jeśli uznałby, że ich działalność jest niezgodna $\mathrm{z}$ dobrem wymiaru sprawiedliwości. Prof. 
Sobczak stwierdził, że sądownictwo powinno być niezależne od władzy sądowniczej, gdyż wynika to z zasady trójpodziału władzy, zaś wszelka ingerencja ministra sprawiedliwości w judykatywę jest niekonstytucyjna i nie powinna mieć miejsca.

Ostatnim z prelegentów występujących na konferencji był dr Jarosław Czerw, wicestarosta powiatu kraśnickiego. W swoim wystąpieniu zatytułowanym Zasady udostępniania informacji publicznej przez partie polityczne $w$ świetle uregulowań polskiej ustawy o dostępie do informacji publicznej zaprezentował ważny problem, jakim jest kwestia udostępniania dokumentów oraz informacji o swojej działalności przez partie polityczne. Według ustawy każda partia polityczna, związek zawodowy i organizacja pracodawców mają obowiązek udostępniać zainteresowanym informacje o swoich celach, zamierzeniach, działalności, strukturze oraz personaliach osób sprawujących kierownicze funkcje. Dr Czerw przedstawił sposoby udostępniania tych danych. Wśród nich najważniejszym jest aktualizowanie internetowego Biuletynu Informacji Publicznej przez dane ugrupowanie polityczne i udostępnianie wnioskodawcy tych informacji, których nie ma w BIP, w ciągu dwóch tygodni od daty wpłynięcia wniosku. Po zakończeniu wystąpienia nastąpiły pytania do prelegentów i dyskusja na przedstawioną przez nich problematykę.

Konferencja zakończyła się wystąpieniem prof. Szmulika i dr. Paździora, którzy podziękowali uczestnikom za liczne przybycie i za owocne obrady. Jednocześnie poinformowali o zasadach przysyłania artykułów do monografii pokonferencyjnej i ostatecznym terminie ich nadsyłania. Zaprosili też wszystkich do udziału w następnej konferencji, organizowanej w 2014 r.

Tomasz Koziełło Uniwersytet Rzeszowski 